\title{
The Performance of Equations That Estimate Glomerular Filtration Rate against Measured Urinary Creatinine Clearance in Critically Ill Patients
}

\author{
Hasan M. Al-Dorzi ${ }^{D}$, Abdulmajeed A. Alsadhan, ${ }^{2}$ Ayman S. Almozaini, ${ }^{2}$ Ali M Alamri, ${ }^{1}$ \\ Hani Tamim, ${ }^{1,3}$ Musharraf Sadat, ${ }^{1}$ Lolowa Al-Swaidan, ${ }^{4}$ Elwaleed Elhassan, \\ and Yaseen M. Arabi ${ }^{1}{ }^{1}$ \\ ${ }^{1}$ College of Medicine, King Saud Bin Abdulaziz University for Health Sciences, \\ King Abdullah International Medical Research Center, Intensive Care Department, King Abdulaziz Medical City, \\ Ministry of National Guard-Health Affairs, Riyadh, Saudi Arabia \\ ${ }^{2}$ College of Medicine, King Saud Bin Abdulaziz University for Health Sciences, \\ King Abdullah International Medical Research Center, Internal Medicine Department, King Abdulaziz Medical City, \\ Ministry of National Guard-Health Affairs, Ministry of National Guard-Health Affairs, Riyadh, Saudi Arabia \\ ${ }^{3}$ Department of Internal Medicine, American University of Beirut, Beirut, Lebanon \\ ${ }^{4}$ College of Pharmacy, King Saud bin Abdulaziz University for Health Sciences, \\ King Abdullah International Medical Research Center, Pharmaceutical Care Department, King Abdulaziz Medical City, \\ Ministry of National Guard-Health Affairs, Riyadh, Saudi Arabia
}

Correspondence should be addressed to Yaseen M. Arabi; yaseenarabi@yahoo.com

Received 22 February 2021; Accepted 5 May 2021; Published 18 May 2021

Academic Editor: Samuel A. Tisherman

Copyright ( $\odot 2021$ Hasan M. Al-Dorzi et al. This is an open access article distributed under the Creative Commons Attribution License, which permits unrestricted use, distribution, and reproduction in any medium, provided the original work is properly cited.

The performance of glomerular filtration rate- (GFR-) estimating equations was studied against creatinine clearance measured by 24-hour urine collection $\left(\mathrm{CrCl}_{24 \mathrm{~h} \text {-urine }}\right)$ in critically ill patients. Methods. In this substudy of the PermiT trial (https://clinicaltrials.

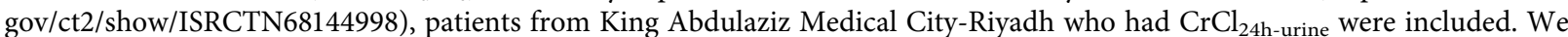
estimated GFR using Cockroft-Gault (CG), modification of diet in renal disease study (MDRD), chronic kidney disease epidemiology collaboration (CKD-EPI), and Jelliffe equations. For the CG equation, we entered the actual weight in one calculation $\left(C G_{\text {actual-wt }}\right)$, and if $B M I \geq 30 \mathrm{~kg} / \mathrm{m}^{2}$, we entered the ideal body weight $\left(C_{\text {ideal-wt }}\right)$ and the adjusted body weight $\left(C_{\text {adjusted-wt }}\right)$ in two calculations. We calculated the MDRD equation based on 4 (MDRD-4) and 6 variables (MDRD-6). The performance of these equations was assessed by different ways including Spearman correlation, bias (difference between estimated $\mathrm{GFR}$ and $\mathrm{CrCl}_{24 \mathrm{~h}-}$ urine), precision (standard deviation of bias), and Bland-Altman plot analysis. Results. The cohort consisted of 237 patients (age $45 \pm 20$ years, males $75 \%$, mechanically ventilated $99 \%$ with serum creatinine $101 \pm 94 \mu \mathrm{mol} / \mathrm{L}$ and $\mathrm{CrCl}_{24 \mathrm{~h}-\text { urine }} 108 \pm 69 \mathrm{ml} / \mathrm{min} /$

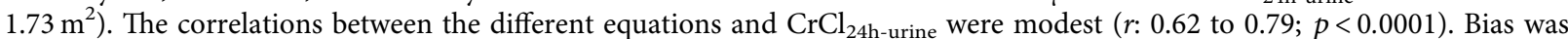
statistically significant for $\mathrm{CG}_{\text {actual-wt }}(21 \mathrm{ml} / \mathrm{min}), \mathrm{CG}_{\text {adjusted-wt }}(12 \mathrm{ml} / \mathrm{min})$, and MDRD-6 $(-10 \mathrm{ml} / \mathrm{min})$ equations. Precision ranged from 46 to $54 \mathrm{ml} / \mathrm{min}$. The sensitivity of equations to correctly classify $\mathrm{CrCl}_{24 \mathrm{~h} \text {-urine }} 30-59.9 \mathrm{ml} / \mathrm{min} / 1.73 \mathrm{~m}^{2}$ was $17.2 \%$ for $\mathrm{CG}_{\text {actual-wt }}, 30.0 \%$ for $\mathrm{CG}_{\text {ideal-wt }}, 31.0 \%$ for $\mathrm{CG}_{\text {adjusted-wt }}, 31.0 \%$ for MDRD-4, 39.1\% for MDRD-6, 13.8\% for CKD-EPI, and 34.5\% for Jelliffe equation. Conclusions. Commonly used GFR-estimating equations had limited ability to properly estimate $\mathrm{CrCl}_{24 \mathrm{~h}-u r i n e}$ and to correctly classify GFR into clinically relevant ranges that usually determine dosing of medications. 


\section{Introduction}

Appropriate dosing of medications is frequently dependent on renal function. The Kidney Disease Improving Global Outcomes (KDIGO) clinical practice guidelines consider GFR as the preferred measure of kidney function rather than serum creatinine $(\mathrm{Cr})$ and recommend estimating GFR in most circumstances and measuring it when greater accuracy is required [1]. To accurately measure GFR, exogenous substances, such as inulin, are used as filtration markers [2]. Despite being the gold standard for assessment of renal function, this measurement is not routinely performed in clinical practice as it is complex, impractical, costly, and not widely available. An alternative is the measurement of urinary $\mathrm{Cr}$ clearance $(\mathrm{CrCl})$. However, the required timed urine collection is cumbersome and prone to errors and the result needs time to be reported. Hence, estimation of GFR using methods that are practical and timely is desirable in all patients in general. This might be more important in critically ill patients as they have increased prevalence of kidney dysfunction [3] and frequently exhibit augmented renal clearance (ARC) $[4,5]$. Hence, proper dosing of medications in these patients would enhance their therapeutic effect, reduce potential toxicities, and improve patient outcomes $[6,7]$.

Multiple equations have been produced to estimate GFR, including Cockroft-Gault (CG) [8], modification of diet in renal disease study (MDRD) [9], chronic kidney disease epidemiology collaboration (CKD-EPI) [10], and Jelliffe [11] equations. These equations are primarily based on serum $\mathrm{Cr}$ and various anthropometric data. They were mostly derived from patients who were not critically ill [8-10]. Hence, there are concerns regarding their use in the ICU setting [12]. Studies that tested the accuracy of these equations in estimating renal function in the ICU setting are not many. Some focused on certain patient groups, especially those with ARC $[13,14]$, while others had low number of patients $[13,15-17]$. The objective of this study was to assess the performance of commonly used formulas that estimate GFR against measured urinary $\mathrm{CrCl}$ in critically ill patients with different degrees of kidney function.

\section{Methods}

2.1. Study Design. This is a substudy of the PermiT (Permissive Underfeeding versus Target Enteral Feeding in Adult Critically Ill Patients) trial (https://clinicaltrials.gov/ ct2/show/ISRCTN68144998), a multicenter randomized controlled trial which compared permissive underfeeding (40-60\% of caloric requirements) versus target feeding (70-100\% of caloric requirements) in ICU patients with similar protein intake in both groups (November 2009 to September 2014) [18]. Eligible patients were those who received tube feeding within 48 hours of ICU admission, were expected to stay in the ICU $>72$ hours, and were not on high doses of vasopressors [18]. The trial found no difference in the primary outcome (90-day mortality: $27.2 \%$ vs. $28.9 \%$, respectively; relative risk: $0.94,95 \% \mathrm{CI}, 0.76-1.16 ; p=0.58$ ) [18]. The trial required serial 24-hour urine collection to measure nitrogen balance. In this retrospective study, we included the patients enrolled in the trial at King Abdulaziz Medical City-Riyadh who had at least one 24-hour urine collection for $\mathrm{Cr}$, allowing $\mathrm{CrCl}\left(\mathrm{CrCl}_{24 \mathrm{~h} \text {-urine }}\right)$ measurement. Patients with end-stage renal disease requiring dialysis and those with anuria for any other reasons were excluded. Subjects with missing variables needed for calculations of the different equations were also excluded. The original trial was approved by the Institutional Review Board of Ministry of National Guard Health Affairs, Riyadh, Saudi Arabia.

2.2. Data Collection. At baseline, we collected data on patients' demographics, chronic comorbid conditions, admission category (medical, surgical, and trauma), presence of traumatic brain injury, presence of sepsis on admission, Acute Physiology and Chronic Health Evaluation (APACHE II) score, Sequential Organ Failure Assessment (SOFA) score, use of mechanical ventilation, need for vasopressor therapy because of shock, daily caloric and protein intake, and laboratory results. We also obtained data about clinical outcomes, including mortality, duration of mechanical ventilation, and length of stay in the ICU and hospital.

In the study patients, urine was collected over 24 hours at baseline and then weekly as required by the trial when

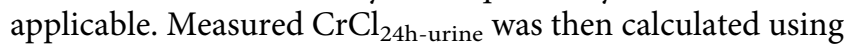
the standard equation: (urine $\mathrm{Cr} \times$ urinary flow in $\mathrm{ml} / \mathrm{min}$ )/ serum $\mathrm{Cr}$, where urine and serum $\mathrm{Cr}$ were expressed in $\mu \mathrm{mol} / \mathrm{L}$. To estimate GFR using different equations, we used the following variables taken on the same day of urine collection: age, weight, serum $\mathrm{Cr}$, blood urea nitrogen, and albumin. In our laboratory, serum and urinary $\mathrm{Cr}$ concentrations were analyzed by a standardized Jaffe method (alkaline picrate reaction) traceable to isotopic dilution mass spectrometry using Abbott Architect c16000 platform.

2.3. Estimation of Kidney Function. We estimated GFR using CG [8], MDRD [9], CKD-EPI [10], and Jelliffe [11] equations. These different equations are described in Table 1. For CG equation, we entered the actual weight in one calculation $\left(\mathrm{CG}_{\text {actual-wt }}\right)$, and if body mass index $(\mathrm{BMI}) \geq 30 \mathrm{~kg} / \mathrm{m}^{2}$, the ideal body weight $\left(\mathrm{CG}_{\text {ideal-wt }}\right)$ and the adjusted body weight $\left(\mathrm{CG}_{\text {adjusted-wt }}\right)$ were used in two calculations. We calculated the MDRD equation based on 4 (MDRD-4) and 6 variables (MDRD-6). Acute kidney injury in the enrollment day was assessed using the KDIGO classification [19].

2.4. Statistical Analysis. Continuous variables were reported as mean and standard deviation (SD). The coefficient of

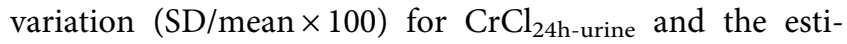
mated GFR were also calculated. Categorical data were presented as frequency with percentage. Chi square test was used to assess between-group differences in categorical variables. Student's $t$ or ANOVA tests were used to assess between-group differences in continuous variables as indicated.

The performance of the GFR-estimating equations

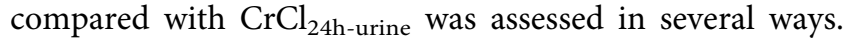


TABLE 1: Renal function estimating equations.

Cockcroft and Gault formula (ml/min)

For males: [(140—age $) \times$ actual $\mathrm{BW}] / \mathrm{sCr} \times 72$

For females: $([(140-$ age $) \times$ actual $\mathrm{BW}] / \mathrm{sCr} \times 72) \times 0.85$

$\mathrm{sCr}$ in $\mathrm{mg} / \mathrm{dL}$

The equation was calculated three times:

(1) Using actual BW for all patients

(2) Using actual BW for patients with BMI $<30 \mathrm{~kg} / \mathrm{m}^{2}$ and ideal BW for those with BMI $>30 \mathrm{~kg} / \mathrm{m}^{2}$

(3) Using actual BW for patients with BMI $<30 \mathrm{~kg} / \mathrm{m}^{2}$ and adjusted BW for those with BMI $>30 \mathrm{~kg} / \mathrm{m}^{2}$

Ideal BW

Males: $50 \mathrm{~kg}+2.3 \mathrm{~kg}$ for each inch above 60 inches of height

Females: $45.5 \mathrm{~kg}+2.3 \mathrm{~kg}$ for each inch above 60 inches of height

Adjusted BW = ideal BW $+[0.4 \times($ actual BW-ideal BW $)]$

Modification of diet in renal disease study equations $\left(\mathrm{ml} / \mathrm{min} / 1.73 \mathrm{~m}^{2}\right)$

Four-variable equation: $175 \times \mathrm{sCr}^{-1.154} \times$ age $^{-0.203} \times 0.742$ (if female)

Six-variable equation: $170 \times \mathrm{sCr}^{-0.999} \times(\text { Age })^{-0.176} \times(0.762$ if patient is female $) \times(\mathrm{BUN})^{-0.170} \times(\text { albumin })^{0.318}$

$\mathrm{sCr}$ in $\mathrm{mg} / \mathrm{dL}$, albumin in $\mathrm{g} / \mathrm{dL}, \mathrm{BUN}$ in $\mathrm{mg} / \mathrm{dL}$; to convert BUN from $\mathrm{mmol} / \mathrm{L}$ to $\mathrm{mg} / \mathrm{dL}$, divide by 0.3571

Chronic kidney disease epidemiology collaboration (CKD-EPI) equations $\left(\mathrm{ml} / \mathrm{min} / 1.73 \mathrm{~m}^{2}\right.$ )

For females with $\mathrm{sCr} \leq 0.7: \mathrm{GFR}=144 \times\left(\mathrm{sCr} / 0.7^{-0.329} \times(0.993)^{\text {age }}\right.$

For females with $\mathrm{sCr}>0.7: \mathrm{GFR}=144 \times(\mathrm{sCcr} / 0.7)^{-1.209} \times(0.993)^{\text {age }}$

For males with $\mathrm{sCr} \leq 0.9$ : $\mathrm{eGFR}=141 \times(\mathrm{sCr} / 0.9)^{-0.411} \times(0.993)^{\text {age }}$

For males with $\mathrm{sCr}>0.9$ : $\mathrm{eGFR}=144 \times(\mathrm{sCr} / 0.9)^{-1.209} \times(0.993)^{\text {age }}$

Age in years and $\mathrm{sCr}$ in $\mathrm{mg} / \mathrm{dL}$

Jelliffe equation $\left(\mathrm{ml} / \mathrm{min} / 1.73 \mathrm{~m}^{2}\right)$

For males: $(98-16) \times($ age $-20 / 20) / \mathrm{sCr}$

For females: $[(98-16) \times($ age $-20 / 20) / s C r] \times 0.9$

Age in years and $\mathrm{sCr}$ in $\mathrm{mg} / \mathrm{dL}$

BUN: blood urea nitrogen, BW: body weight, sCr: serum creatinine

Correlations were reported using Spearman correlation coefficient $(r)$. Bias represented the mean difference between $\mathrm{CrCl}_{24 h \text {-urine }}$ and each of the equations estimating GFR [20]. Precision was defined as one SD of the bias [20]. Error was defined as double SD of the bias divided by the mean of the equation under study and $\mathrm{CrCl}_{24 \mathrm{~h} \text {-urine. }}$ An acceptable between-method error was defined as $30 \%$ or less [21]. Accuracy was defined as percentage of GFR estimations within $\pm 15, \pm 30$, and $\pm 50 \%$ range of respective $\mathrm{CrCl}_{24 \text { h-urine }}$ measurements. The 2002 Kidney Disease Outcomes Quality Initiative guidelines recommended that $\geq 90 \%$ of estimates be within 30\% [22]. Bland-Altman plots were generated by plotting bias on the $Y$-axis and the mean of the equation under study and $\mathrm{CrCl}_{24 \mathrm{~h} \text {-urine }}$ on the $X$-axis [23]. The limits of agreement (bias \pm two SD of the bias) were shown in the plots.

The predictive performance of the different equations was assessed when $\mathrm{CrCl}_{24 \mathrm{~h} \text {-urine }}$ was $<30,30-59.9,60-130$, and $>130 \mathrm{ml} / \mathrm{min}$. We also assessed the ability (sensitivity) of the different equations to correctly classify $\mathrm{CrCl}_{24 \mathrm{~h} \text {-urine }}$ within clinically relevant ranges $(<30,30-59.9,60-130$, and $>130 \mathrm{ml} / \mathrm{min}$ ). Moreover, Spearman correlation was calculated in selected subgroups of patients: age $<$ versus $\geq 65$ years, $\quad \mathrm{BMI}<$ versus $\geq 30 \mathrm{~kg} / \mathrm{m}^{2}$, APACHE II score $<$ versus $\geq$ median value, which was 20 , admission categories (medical, surgical, and nonoperative trauma), diagnosis of traumatic brain injury, presence of sepsis on ICU admission, baseline $\mathrm{Cr}<$ versus $\geq 110 \mu \mathrm{mol}$, presence of $\mathrm{AKI}$, and presence of ARC (baseline $\mathrm{CrCl}_{24 \mathrm{~h} \text {-urine }}>130 \mathrm{ml} /$ $\left.\mathrm{min} / 173 \mathrm{~m}^{2}\right)[4,5]$.
Tests were two-sided and statistical significance was determined at $p<0.05$. Bias was considered significant if the null hypothesis (bias $=0$ ) was rejected. Analyses were conducted using SAS version 9.2 (SAS Institute, Cary, NC) and SPSS version 15 .

\section{Results}

3.1. Characteristics of Patients. Two hundred and thirtyseven patients were included in this study. Table 2 describes their characteristics. The mean age was $45.0 \pm 20.2$ years, $74.7 \%$ were men, $32.5 \%$ were obese (BMI $>30 \mathrm{~kg} / \mathrm{m}^{2}$ ), $31.7 \%$ had diabetes, $98.7 \%$ required mechanical ventilation, and $26.2 \%$ had traumatic brain injury.

The baseline serum $\mathrm{Cr}$ was $100.8 \pm 93.9 \mu \mathrm{mol} / \mathrm{L}$. Most patients $(53 \%)$ had 24 -hour urine collection once, $17.7 \%$ twice, $13.9 \%$ three times, and $15.2 \%$ four times. Thus, there were 453 measurements of urinary $\mathrm{CrCl}$. Whereas $18.1 \%$ had AKI, $38.4 \%$ had ARC based on $\mathrm{CrCl}_{24 \mathrm{~h} \text {-urine }}>130 \mathrm{ml} / \mathrm{min}$ at baseline. The measured $\mathrm{CrCl}_{24 \mathrm{~h} \text {-urine }}$ and estimated GFRs based on the various equations are presented in Figure 1. The mean $\mathrm{CrCl}_{24 \mathrm{~h} \text {-urine }}$ was $108.4 \pm 68.9 \mathrm{ml} / \mathrm{min}$ in the first 237 measurements. The estimated GFR by the different equations were $129.6 \pm 65.6 \mathrm{ml} / \mathrm{min}$ for $\mathrm{CG}_{\text {actual-wt }}(p=0.001)$, $113.5 \pm 59.2 \mathrm{ml} / \mathrm{min}$ for $\mathrm{CG}_{\text {ideal-wt }}(p=0.39), 119.9 \pm 59.9$ for $\mathrm{CG}_{\text {adjusted-wt }}(p=0.053), \quad 108.9 \pm 52.5 \mathrm{ml} / \mathrm{min}$ for MDRD-4 $(p=0.93), 102.2 \pm 48.7 \mathrm{ml} / \mathrm{min}$ for MDRD-6 $(p=0.27), 102.1 \pm 40.4 \mathrm{ml} / \mathrm{min}$ for CKD-EPI $(p=0.22)$, and $102.0 \pm 49.3 \mathrm{ml} / \mathrm{min}$ for Jelliffe equation $(p=0.24)$. However, precision was high for all equations. 
TABle 2: Characteristics and outcomes of the 237 patients in the study cohort.

\begin{tabular}{|c|c|}
\hline & $\begin{array}{l}\text { All patients } \\
\quad N=237\end{array}$ \\
\hline Age-(year), mean $\pm \mathrm{SD}$ & $45.0 \pm 20.2$ \\
\hline Female sex-no. (\%) & $60(25.3)$ \\
\hline Height- $(\mathrm{cm})$, mean $\pm \mathrm{SD}$ & $166.3 \pm 9.7$ \\
\hline Weight- $(\mathrm{kg})$, mean $\pm \mathrm{SD}$ & $78.2 \pm 19.6$ \\
\hline Body mass index- $\left(\mathrm{kg} / \mathrm{m}^{2}\right)$, mean $\pm \mathrm{SD}$ & $28.3 \pm 7.2$ \\
\hline \multicolumn{2}{|l|}{ Chronic illnesses-no. (\%) } \\
\hline Diabetes & $75(31.7)$ \\
\hline Chronic respiratory disease & $27(11.3)$ \\
\hline Chronic cardiac disease & $23(9.7)$ \\
\hline Immunocompromised disorder & $6(2.5)$ \\
\hline Chronic renal disease & $6(2.5)$ \\
\hline Chronic liver disease & $11(4.6)$ \\
\hline \multicolumn{2}{|l|}{ Admission category, no. (\%) } \\
\hline Medical & $11247.3)$ \\
\hline Surgical & $11(4.6)$ \\
\hline Nonoperative trauma & $114(48.1)$ \\
\hline Traumatic brain injury-no. (\%) & $62(26.2)$ \\
\hline Sepsis on admission-no. (\%) & $51(21.5)$ \\
\hline$A P A C H E I I-$ mean $\pm \mathrm{SD}$ & $20.4 \pm 8.1$ \\
\hline SOFA score day $1-$ mean $\pm \mathrm{SD}$ & $10.0 \pm 2.8$ \\
\hline Vasopressor use-no. (\%) & $135(57.0)$ \\
\hline Mechanical ventilation-no. (\%) & $234(98.7)$ \\
\hline \multicolumn{2}{|l|}{ Intervention group-no. (\%) } \\
\hline Standard feeding & $120(50.6)$ \\
\hline Permissive underfeeding & $117(49.4)$ \\
\hline Total caloric intake (kcal/day) - mean $\pm \mathrm{SD}$ & $1143.6 \pm 466.1$ \\
\hline Total protein intake-(g/day) mean $\pm \mathrm{SD}$ & $55.9 \pm 21.0$ \\
\hline \multicolumn{2}{|l|}{ Laboratory tests } \\
\hline $\begin{array}{l}\text { Inclusion blood glucose- }(\mathrm{mmol} / \mathrm{L}) \\
\text { mean } \pm \mathrm{SD}\end{array}$ & 9.04 .1 \\
\hline Creatinine $-(\mu \mathrm{mol} / \mathrm{L})$, mean $\pm \mathrm{SD}$ & $100.8 \pm 93.9$ \\
\hline Bilirubin $-(\mu \mathrm{mol} / \mathrm{L})$, mean $\pm \mathrm{SD}$ & $25.4 \pm 39.2$ \\
\hline Platelets- $\left(10^{9} / \mathrm{L}\right)$, mean \pm SD & $214 \pm 128$ \\
\hline Albumin- $(\mathrm{g} / \mathrm{L})$, mean $\pm \mathrm{SD}$ & $28.8 \pm 5.6$ \\
\hline \multicolumn{2}{|l|}{ Outcomes } \\
\hline $\begin{array}{l}\text { Mechanical ventilation duration-(days), } \\
\text { mean } \pm \text { SD }\end{array}$ & $13.0 \pm 25.0$ \\
\hline ICU LOS-(days), mean \pm SD & $15.9 \pm 10.5$ \\
\hline Hospital LOS-(days), mean \pm SD & $59.3 \pm 83.1$ \\
\hline 90-day mortality & $61(25.7)$ \\
\hline ICU mortality-no. (\%) & $38(16.0)$ \\
\hline Hospital mortality-no. (\%) & $56(23.6)$ \\
\hline ICU-acquired infections-no. (\%) & $96(40.5)$ \\
\hline
\end{tabular}

SD: standard deviation; APACHE: acute physiology and chronic health evaluation; SOFA: sequential organ failure assessment; ICU: intensive care unit; LOS: length of stay.

3.2. Performance of the Equations Estimating GFR in the Whole Cohort. The performance of the different GFR-esti-

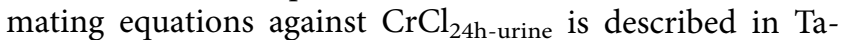
ble 3. The correlations between the different equations and

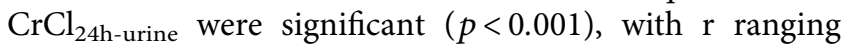
between 0.62 and 0.79 . When using the first 237 urine measurements, bias was large and statistically significant for $\mathrm{CG}_{\text {actual-wt }}(21.1 \mathrm{ml} / \mathrm{min}), \mathrm{CG}_{\text {adjusted-wt }}(11.5 \mathrm{ml} / \mathrm{min})$, and MDRD-6 (-10.3 $\mathrm{ml} / \mathrm{min})$ equations. When using all 453 urine measurements, the bias was large and statistically significant for $\mathrm{CG}_{\text {actual-wt }}(27.4 \mathrm{ml} / \mathrm{min}), \mathrm{CG}_{\text {ideal-wt }}(12.3 \mathrm{ml} /$ min) $C_{\text {adjusted-wt }}(18.3 \mathrm{ml} / \mathrm{min})$, MDRD-4 $(7.1 \mathrm{ml} / \mathrm{min})$, and MDRD-6 (-5.7 $\mathrm{ml} / \mathrm{min})$ equations. In both calculations, CKD-EPI and Jelliffe equations had no significant bias. The error was $>70 \%$ for all equations.

The accuracy values for the different equations were generally modest. When using the first 237 urine measurements, accuracy within $\pm 10 \%$ of $\mathrm{CrCl}_{24 \mathrm{~h} \text {-urine }}$ ranged between $12.7 \%\left(\mathrm{CG}_{\text {actual-wt }}\right.$ equation) and $30.0 \%$ ( $\mathrm{CG}_{\text {adjusted-wt }}$ equation). Accuracy within $\pm 30 \%$ ranged between $47.4 \%$ (MDRD6 equation) and $51.2 \%$ ( $\mathrm{CG}_{\text {adjusted-wt }}$ equation). Accuracy within $\pm 57.4 \%$ ranged between $12.7 \%$ (Jelliffe equation) and $75.1 \%$ (MDRD-6 equation). The accuracy values were similar when all 453 measurements were used in calculation (Table 3).

Bland-Altman plots are depicted in Figure 2. The limits of agreement were 111.3 and $-69.0 \mathrm{ml} / \mathrm{min}$ for $\mathrm{CG}_{\text {actual-wt, }}$ 103.0 and -92.9 for $\mathrm{CG}_{\text {ideal-wt }}, 101.4$ and $-78.4 \mathrm{ml} / \mathrm{min}$ for $\mathrm{CG}_{\text {adjusted-wt, }} 106.7$ and $-105.7 \mathrm{ml} / \mathrm{min}$ for MDRD-4, 95.2 and $-116.2 \mathrm{ml} / \mathrm{min}$ for MDRD-6, 94.8 and $-107.4 \mathrm{ml} / \mathrm{min}$ for CKD-EPI, and 95.2 and $-108.1 \mathrm{ml} / \mathrm{min}$ for Jelliffe equations. Multiple points were outside the limits of agreement, which were wide for all equations.

\subsection{Performance of the Equations Estimating GFR in Different} Ranges of Urinary Creatinine Clearance and in Selected Subgroups of Patients. Correlation, bias, precision, and accuracy for the different equations are reported in Table 3 when $\mathrm{CrCl}_{24 \mathrm{~h} \text {-urine }}<30,30-59.9,60-130$, and $>130 \mathrm{ml} / \mathrm{min}$ using the 453 measurements, which were considered to be independent observations. Bias was significant for all equations except for $\mathrm{CG}_{\text {adjusted-wt }}$ equation when $\mathrm{CrCl}_{24 \text { h-urine }}>$ $130 \mathrm{ml} / \mathrm{min}$.

The sensitivity of GFR equations to correctly classify $\mathrm{CrCl}_{24 \mathrm{~h} \text {-urine }}<30 \mathrm{ml} / \mathrm{min}$ was $44.7 \%$ for $\mathrm{CG}_{\text {actual-wt }}, 71.1 \%$ for $\mathrm{CG}_{\text {ideal-wt }}, 57.9 \%$ for $\mathrm{CG}_{\text {adjusted-wt }}, 60.5 \%$ for MDRD-4, $64.5 \%$ for MDRD-6, 59.5\% for CKD-EPI, and 60.5\% for Jelliffe equation. The sensitivity to correctly classify $\mathrm{CrCl}_{24 \mathrm{~h} \text {-urine }}$ $30-59.9 \mathrm{ml} / \mathrm{min}$ was $17.2 \%$ for $\mathrm{CG}_{\text {actual-wt }} 30.0 \%$ for $\mathrm{CG}_{\text {ideal-wt }}$, $31.0 \%$ for $\mathrm{CG}_{\text {adjusted-wt }}, 31.0 \%$ for MDRD-4, 39.1\% for MDRD-6, 13.8\% for CKD-EPI, and 34.5\% for Jelliffe equation. The sensitivity to correctly classify $\mathrm{CrCl}_{24 \mathrm{~h} \text {-urine }} 60-129.9$ $\mathrm{ml} / \mathrm{min}$ was $59.5 \%$ for $\mathrm{CG}_{\text {actual-wt }}, 60.8 \%$ for $\mathrm{CG}_{\text {ideal-wt }}, 63.3 \%$ for $\mathrm{CG}_{\text {adjusted-wt }}$ 58.2\% for MDRD-4, 59.7\% for MDRD-6, $79.7 \%$ for CKD-EPI, and $63.3 \%$ for Jelliffe equation. The sensitivity to correctly classify $\mathrm{CrCl}_{24 \mathrm{~h} \text {-urine }} \geq 130 \mathrm{ml} / \mathrm{min}$ was $87.9 \%$ for $\mathrm{CG}_{\text {actual-wt }}, 70.3 \%$ for $\mathrm{CG}_{\text {ideal-wt }}, 79.1 \%$ for $\mathrm{CG}_{\text {adjusted-wt }}, 60.4 \%$ for MDRD-4, 49.4\% for MDRD-6, $45.1 \%$ for CKD-EPI, and $53.3 \%$ for Jelliffe equation.

Table 4 shows the Spearman correlations between the different GFR-estimating equations and $\mathrm{CrCl}_{24 \mathrm{~h} \text {-urine }}$. The values of $r$ were lowest in patients with the diagnosis of polytrauma, baseline $\mathrm{Cr}<110 \mu \mathrm{mol}$ and baseline $\mathrm{CrCl}_{24 \text { h-urine }}>130 \mathrm{ml} / \mathrm{min}$.

\section{Discussion}

In this study, we found that the commonly used equations to estimate GFR performed modestly against the measured 


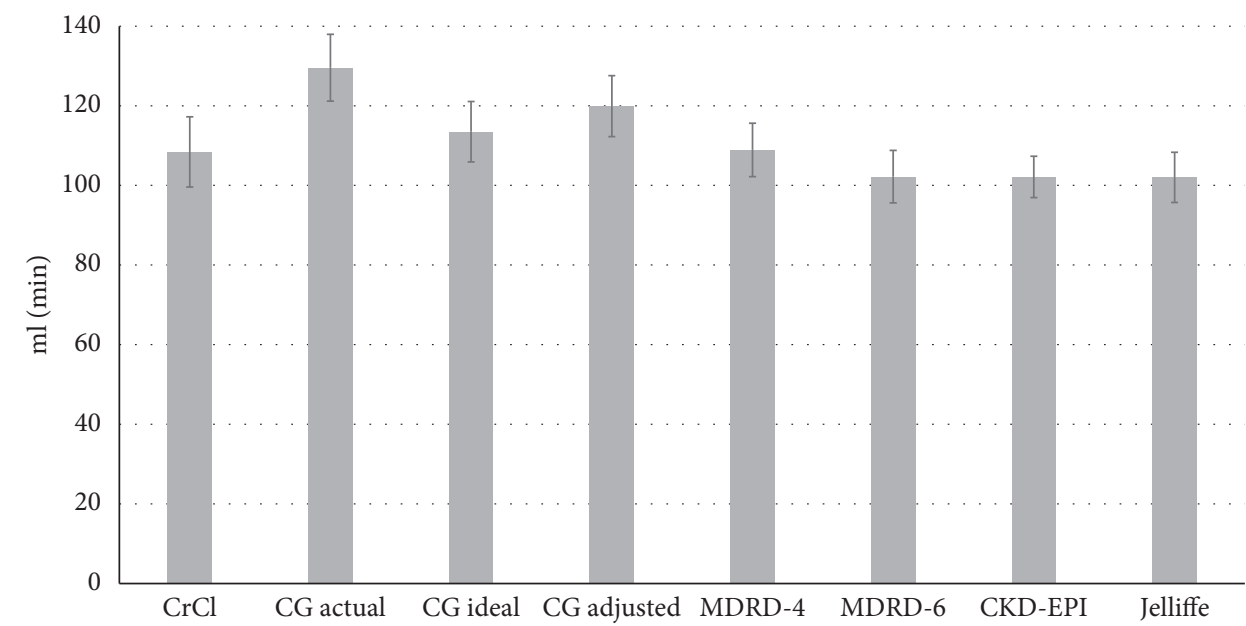

FIGURE 1: Mean values of the measured creatinine clearance by 24 -hour urine collection $\left(\mathrm{CrCl}_{24 \mathrm{~h} \text {-urine }}\right)$ and estimated glomerular filtration rate by different equations. The first 23724 -hour urine samples were used in this analysis. Error bars represent $95 \%$ confidence interval. The difference between the different methods was significant $(p<0.001)$ by ANOVA test. CG: Cockroft-Gault equation; MDRD-4: 4 -variable modification of diet in renal disease equation; MDRD-6: 6-variable modification of diet in renal disease equation, and CKD-EPI: chronic kidney disease epidemiology collaboration equation.

urinary $\mathrm{CrCl}$ with high bias and accuracy within $30 \%$ present in approximately 50\%. The equations with the highest

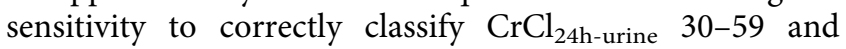
$\geq 130 \mathrm{ml} / \mathrm{min}$, ranges where medication dose adjustment is frequently needed, were MDRD-6 and CG actual-wt .

Measuring GFR cannot be done routinely. Measured urinary $\mathrm{CrCl}$ is more widely available, but it may overestimate GFR because of Cr filtration and secretion; the latter can be affected by medications known to compete with active tubular secretion of $\mathrm{Cr}$ [24]. However, studies that compared $\mathrm{CrCl}_{24 \mathrm{~h}}$ urine with measured GFR in the ICU are limited. One study found that urinary $\mathrm{CrCl}$ with short collection times $(1-2 \mathrm{~h})$ had the highest correlation with measured GFR using inulin clearance $(r=0.921)$. The median bias for measured urinary $\mathrm{CrCl}$ was $11 \mathrm{~mL} / \mathrm{min} / 1.73 \mathrm{~m}^{2}$ for GFR $<60 \mathrm{ml} / \mathrm{min}, 24 \mathrm{~mL} /$ $\mathrm{min} / 1.73 \mathrm{~m}^{2}$ for GFR $60-90 \mathrm{ml} / \mathrm{min}$, and $44 \mathrm{~mL} / \mathrm{min} / 1.73 \mathrm{~m}^{2}$ for $\mathrm{GFR}>90 \mathrm{ml} / \mathrm{min}$ [17]. Another study evaluated $30 \mathrm{ICU}$ patients with early AKI after complicated cardiac surgery and found low bias but high error when $\mathrm{CrCl}_{24 \mathrm{~h} \text {-urine was com- }}$ pared with GFR measured by the infusion clearance of chromium-ethylenediaminetetraacetic acid [15]. The magnitude of this overestimation increased as GFR declined [15]. On the other hand, the commonly used equations to estimate GFR have their own shortcomings. They were mostly derived from outpatients with stable kidney function [8-10]. Only the Jelliffe equation was validated to assess GFR in a non-steady state as in critically ill patients [25]. Besides, studies that evaluated their use in the ICU settings had many limitations. Nevertheless, they generally found modest performance of GFR-estimating equations. A study of 360 critically ill patients who had stable serum $\mathrm{Cr}$ in one French hospital compared estimated GFR by equations that included CG, MDRD, and

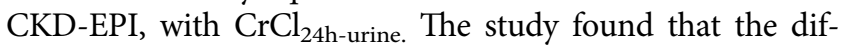
ferent equations tended to overestimate the $\mathrm{CrCl}$ for low eGFR values and to underestimate the $\mathrm{CrCl}$ for normal and high values [26]. In patients without $\mathrm{ARC}$, the bias and precision were 11.3 and $25.3 \mathrm{ml} / \mathrm{min}$ for CKD-EPI, 18.8 and
$31.7 \mathrm{ml} / \mathrm{min}$ for CG, and 22.5 and $34.6 \mathrm{ml} / \mathrm{min}$, respectively [26]. Another study of 360 ICU subjects in Australia found that all tested equations (CG and CKD-EPI) showed limited agreement with 8-hour urinary $\mathrm{CrCl}$ [27]. $\mathrm{CG}_{\text {actual-wt }}$ corrected for body surface area had the lowest bias $(-3.2 \mathrm{ml} / \mathrm{min}$ for indigenous and $8.2 \mathrm{ml} / \mathrm{min}$ for nonindigenous patients) [27]. However, CKD-EPI had the narrowest $95 \%$ confidence interval for limits of agreement in the Bland-Altman analysis [27]. A study of 111 patients without renal impairment in a Japanese ICU found that eGFR calculated using the Japanese equation correlated well with $\mathrm{CrCl}$ based on 8-hour urine collection (Spearman $r=0.75 ; p<0.05$ ) [28]. In contrast, the Bland-Altman plots showed that the bias of the two variables was $-46.1 \mathrm{~mL} / \mathrm{min} / 1.73 \mathrm{~m}^{2}$, and the $95 \%$ limits of agreement were -128.9 to $36.7 \mathrm{~mL} / \mathrm{min} / 1.73 \mathrm{~m}^{2}$ [28]. In a study of 54 ICU patients with normal $\mathrm{Cr}$, a statistically significant, but poor, correlation was noted between CrCL by 8-hour urine collection and GFR estimated by CG, MDRD-4, and CKDEPI $(r=0.20,0.19$, and 0.34 , respectively) [16], The Bland-Altman plot showed poor agreement between pairs of comparisons (precision of 40.9, 39.8, and 33.4\%, respectively) [16], When GFR-estimating equations were compared with measured GFR by inulin clearance in the ICU, CG, MDRD-6, MDRD-4, and CKD-EPI equations overestimated GFR (bias $24,26,37$, and $13 \mathrm{~mL} / \mathrm{min} / 1.73 \mathrm{~m}^{2}$, respectively) [17]. However, CKD-EPI had the lowest bias likely due to its better performance when GFR $>90 \mathrm{~mL} / \mathrm{min} / 1.73 \mathrm{~m}^{2}$ [17]. We evaluated seven different equations against $\mathrm{CrCl}_{24 \mathrm{~h} \text {-urine. All }}$ had significant bias, inadequate precision, high error, low accuracy, and wide agreement limits on the Bland-Altman plots. The correlations were moderate to strong nevertheless. Importantly, the sensitivity to correctly identify $\mathrm{CrCl}_{24 \mathrm{~h} \text {-urine }}$ in the clinically important ranges (such as $30-59$ and $>130 \mathrm{ml} /$ $\mathrm{min}$ ) was low in general for all equations.

Studies on the performance of GFR-estimating equations in critically ill patients with AKI are scarce. One study evaluated 30 ICU patients with early AKI. GFR-estimating 
TABLE 3: Predictive performance of equations estimating glomerular filtration rate compared with creatinine clearance $\left(\mathrm{CrCl}_{24 \mathrm{~h}-\mathrm{urine}}\right)$ measured by 24-hour urine collection.

\begin{tabular}{|c|c|c|c|c|c|c|c|c|}
\hline & $\mathrm{CrCl}_{24 \mathrm{~h} \text {-urine }}$ & $\mathrm{CG}_{\text {actual-wt }}$ & $\mathrm{CG}_{\text {ideal-wt }}$ & $\mathrm{CG}_{\text {adjusted-wt }}$ & MDRD-4 & MDRD-6 & CKD-EPI & Jelliffe \\
\hline \multicolumn{9}{|c|}{ Data from the first 237 urine collections (all 237 patients) } \\
\hline $\begin{array}{l}\text { GFR estimate }(\mathrm{mlH} / \mathrm{min}) \\
\pm \mathrm{SD}\end{array}$ & $108.4 \pm 68.9$ & $129.6 \pm 65.6$ & $113.5 \pm 59.2$ & $119.9 \pm 59.9$ & $108.9 \pm 52.5$ & $102.2 \pm 48.7$ & $102.1 \pm 40.4$ & $102.0 \pm 49.3$ \\
\hline $\begin{array}{l}\text { Coefficient of variation } \\
(\%)\end{array}$ & 63.6 & 50.6 & 52.2 & 50.0 & 48.2 & 47.7 & 39.6 & 48.3 \\
\hline Correlation & & 0.77 & 0.71 & 0.75 & 0.63 & 0.62 & 0.67 & 0.66 \\
\hline $\operatorname{Bias}(\mathrm{ml} / \mathrm{min})$ & & $21.1^{*}$ & 5.0 & $11.5^{*}$ & 0.5 & $-10.5^{*}$ & -6.3 & -6.4 \\
\hline Precision $(\mathrm{ml} / \mathrm{min})$ & & \pm 46.0 & \pm 49.9 & \pm 45.9 & \pm 54.2 & \pm 53.9 & \pm 51.6 & \pm 51.9 \\
\hline Error $(\%)$ & & 77.3 & 90.0 & 80.4 & 99.7 & 100.4 & 98.0 & 98.6 \\
\hline \multicolumn{9}{|l|}{ Accuracy } \\
\hline $\pm 15 \%$ & & 12.7 & 27.4 & 30.0 & 25.7 & 22.8 & 28.3 & 25.7 \\
\hline $\pm 30 \%$ & & 49.4 & 48.1 & 51.2 & 48.9 & 47.4 & 48.9 & 49.4 \\
\hline $\pm 50 \%$ & & 66.7 & 72.2 & 71.3 & 69.2 & 75.1 & 70.5 & 57.4 \\
\hline \multicolumn{9}{|c|}{ Data from the 453 urine collections (all 237 patients) } \\
\hline $\begin{array}{l}\text { GFR estimate }(\mathrm{ml} / \mathrm{min}) \\
\pm \mathrm{SD}\end{array}$ & $102.7 \pm 65.4$ & $130.1 \pm 65.9$ & $114.9 \pm 60.2$ & $121.0 \pm 60.6$ & $109.8 \pm 52.1$ & $99.8 \pm 47.1$ & $103.2 \pm 40.0$ & $103.2 \pm 49.3$ \\
\hline $\begin{array}{l}\text { Coefficient of variation } \\
(\%)\end{array}$ & 63.7 & 50.7 & 52.4 & 50.1 & 47.4 & 47.2 & 38.8 & 47.8 \\
\hline Correlation & & 0.79 & 0.75 & 0.79 & 0.67 & 0.66 & 0.67 & 0.70 \\
\hline $\operatorname{Bias}(\mathrm{ml} / \mathrm{min})$ & & $27.4^{*}$ & $12.3^{*}$ & $18.3^{*}$ & $7.1^{*}$ & $-5.7^{*}$ & 0.53 & 0.53 \\
\hline Precision $(\mathrm{ml} / \mathrm{min})$ & & \pm 43.0 & \pm 44.3 & \pm 40.9 & \pm 49.1 & \pm 49.3 & \pm 47.2 & \pm 46.8 \\
\hline Error $(\%)$ & & 73.9 & 81.5 & 73.2 & 92.5 & 96.1 & 91.8 & 90.9 \\
\hline \multicolumn{9}{|l|}{ Accuracy } \\
\hline $\pm 15 \%$ & & 24.1 & 27.8 & 29.1 & 26.7 & 27.5 & 28.0 & 26.7 \\
\hline $\pm 30 \%$ & & 42.8 & 47.5 & 49.2 & 49.9 & 50.5 & 50.3 & 50.8 \\
\hline $\pm 50 \%$ & & 60.0 & 69.3 & 66.2 & 69.3 & 73.5 & 69.8 & 72.2 \\
\hline \multicolumn{9}{|c|}{ Urine collections with $\mathrm{CrCl}_{24 h \text {-urine }}<30 \mathrm{ml} / \mathrm{min}(\mathrm{N}=72)$} \\
\hline $\begin{array}{l}\text { GFR estimate }(\mathrm{ml} / \mathrm{min}) \\
\pm \text { SD }\end{array}$ & $13.3 \pm 8.4$ & $39.7 \pm 25.7$ & $30.8 \pm 25.7$ & $34.4 \pm 25.6$ & $34.4 \pm 33.3$ & $32.1 \pm 28.4$ & $38.2 \pm 30.6$ & $33.7 \pm 27.9$ \\
\hline $\begin{array}{l}\text { Coefficient of variation } \\
(\%)\end{array}$ & 63.2 & 64.7 & 83.4 & 74.4 & 96.8 & 88.5 & 80.1 & 82.8 \\
\hline Correlation & & 0.58 & 0.50 & 0.54 & 0.55 & 0.58 & 0.56 & 0.54 \\
\hline $\operatorname{Bias}(\mathrm{ml} / \mathrm{min})$ & & $26.4^{*}$ & $17.6^{*}$ & $21.1^{*}$ & $21.1^{*}$ & $18.7^{*}$ & $25.0^{*}$ & $20.4^{*}$ \\
\hline Precision (ml/min) & & \pm 21.9 & \pm 22.7 & \pm 21.8 & \pm 29.5 & \pm 24.4 & \pm 26.9 & \pm 24.4 \\
\hline \multicolumn{9}{|l|}{ Accuracy } \\
\hline $\pm 15 \%$ & & 1.4 & 16.7 & 5.6 & 12.5 & 13.1 & 11.1 & 8.3 \\
\hline $\pm 30 \%$ & & 6.9 & 23.6 & 15.3 & 26.4 & 27.9 & 23.6 & 19.4 \\
\hline $\pm 50 \%$ & & 11.1 & 36.1 & 23.6 & 36.1 & 39.3 & 30.6 & 31.9 \\
\hline \multicolumn{9}{|c|}{ Urine collections with $\mathrm{CrCl}_{24 h \text {-urine }} 30-59.9 \mathrm{ml} / \mathrm{min}(\mathrm{N}=68)$} \\
\hline $\begin{array}{l}\text { GFR estimate }(\mathrm{ml} / \mathrm{min}) \\
\pm \mathrm{SD}\end{array}$ & $45.3 \pm 8.6$ & $85.6 \pm 34.5$ & $76.9 \pm 37.3$ & $80.4 \pm 35.4$ & $84.8 \pm 40.6$ & $73.8 \pm 36.5$ & $86.3 \pm 29.5$ & $76.0 \pm 35.3$ \\
\hline Correlation & & 0.44 & 0.46 & 0.46 & 0.30 & 0.46 & 0.35 & 0.33 \\
\hline $\begin{array}{l}\text { Coefficient of variation } \\
(\%)\end{array}$ & 19.0 & 40.3 & 48.5 & 44.0 & 47.9 & 49.5 & 34.2 & 46.4 \\
\hline $\operatorname{Bias}(\mathrm{ml} / \mathrm{min})$ & & $40.3^{*}$ & $31.6^{*}$ & $35.1^{*}$ & $39.5^{*}$ & $28.4^{*}$ & $41.0^{*}$ & $30.6^{*}$ \\
\hline Precision $(\mathrm{ml} / \mathrm{min})$ & & \pm 31.7 & \pm 34.3 & \pm 32.4 & \pm 38.9 & \pm 33.5 & \pm 27.6 & \pm 33.5 \\
\hline \multicolumn{9}{|l|}{ Accuracy } \\
\hline $\pm 15 \%$ & & 5.9 & 11.8 & 14.7 & 7.4 & 15.5 & 7.4 & 11.8 \\
\hline $\pm 30 \%$ & & 16.2 & 26.5 & 25.0 & 20.6 & 32.8 & 14.7 & 35.3 \\
\hline $\pm 50 \%$ & & 27.9 & 44.1 & 39.7 & 38.2 & 53.4 & 23.5 & 51.5 \\
\hline \multicolumn{9}{|c|}{ Urine collections with $\mathrm{CrCl}_{24 h \text {-urine }} 60-129.9 \mathrm{ml} / \mathrm{min}(\mathrm{N}=156)$} \\
\hline & $97.8 \pm 20.5$ & $134.2 \pm 44.5$ & $121.6 \pm 43.8$ & $126.6 \pm 41.9$ & $120.8 \pm 37.6$ & $107.7 \pm 35.5$ & $114.2 \pm 26.4$ & $111.7 \pm 36.2$ \\
\hline $\begin{array}{l}\text { Coefficient of variation } \\
\text { (\%) }\end{array}$ & 21.0 & 33.2 & 36.0 & 33.1 & 31.1 & 33.0 & 23.1 & 32.4 \\
\hline Correlation & & 0.37 & 0.38 & 0.40 & 0.12 & 0.18 & 0.32 & 0.23 \\
\hline Bias (ml/min) & & $36.4^{*}$ & $23.8^{*}$ & $28.8^{*}$ & $23.0^{*}$ & $9.6^{*}$ & $16.4^{*}$ & $13.9^{*}$ \\
\hline
\end{tabular}


TABLE 3: Continued.

\begin{tabular}{|c|c|c|c|c|c|c|c|c|}
\hline & $\mathrm{CrCl}_{24 \mathrm{~h} \text {-urine }}$ & $\mathrm{CG}_{\text {actual-wt }}$ & $\mathrm{CG}_{\text {ideal-wt }}$ & $\mathrm{CG}_{\text {adjusted-wt }}$ & MDRD-4 & MDRD-6 & CKD-EPI & Jelliffe \\
\hline Precision $(\mathrm{ml} / \mathrm{min})$ & & \pm 41.6 & \pm 40.6 & \pm 38.7 & \pm 40.7 & \pm 37.6 & \pm 20.7 & \pm 37.2 \\
\hline \multicolumn{9}{|l|}{ Accuracy } \\
\hline $\pm 15 \%$ & & 24.4 & 27.6 & 29.5 & 27.6 & 32.6 & 42.3 & 28.8 \\
\hline $\pm 30 \%$ & & 44.2 & 46.2 & 49.4 & 53.8 & 54.5 & 61.5 & 55.8 \\
\hline $\pm 50 \%$ & & 66.7 & 71.8 & 69.2 & 72.4 & 73.1 & 84.0 & 78.8 \\
\hline
\end{tabular}

Urine collection with $\mathrm{CrCl}_{24 h \text {-urine }}>130 \mathrm{ml} / \mathrm{min}(\mathrm{N}=157)$

GFR estimate $(\mathrm{ml} / \mathrm{min})$

$\pm \mathrm{SD}$

Coefficient of variation

\begin{tabular}{|c|c|c|c|c|c|c|c|c|}
\hline (\%) & 24.0 & 23.7 & 23.0 & 19.9 & 22.4 & 23.4 & 12.6 & 22.6 \\
\hline Correlation & & 0.29 & 0.20 & 0.28 & 0.22 & 0.14 & 0.14 & 0.20 \\
\hline $\operatorname{Bias}(\mathrm{ml} / \mathrm{min})$ & & $13.3^{*}$ & $-10.0^{*}$ & -0.7 & $-29.2^{*}$ & $-43.7^{*}$ & $-44.0^{*}$ & $-34.9^{*}$ \\
\hline Precision (ml/min) & & \pm 51.3 & \pm 50.0 & \pm 45.8 & \pm 46.7 & \pm 48.2 & \pm 42.5 & \pm 46.8 \\
\hline \multicolumn{9}{|l|}{ Accuracy } \\
\hline $\pm 15 \%$ & & 42.0 & 40.1 & 45.9 & 40.8 & 33.1 & 30.6 & 39.5 \\
\hline $\pm 30 \%$ & & 69.4 & 68.8 & 75.2 & 69.4 & 57.4 & 66.9 & 66.9 \\
\hline $\pm 50 \%$ & & 89.8 & 93.0 & 94.3 & 94.9 & 88.5 & 93.6 & 93.0 \\
\hline
\end{tabular}

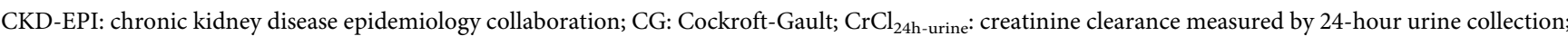
GFR: glomerular filtration rate; MDRD: modification of diet in renal disease study; SD: standard deviation. $\mathrm{CG}_{\text {actual-wt }}$ the CG equation was calculated using actual body weight. $\mathrm{CG}_{\text {ideal-wt }}$ the $\mathrm{CG}$ equation was calculated using ideal body weight. $\mathrm{CG}_{\text {adjusted-wt }}$ the $\mathrm{CG}$ equation was calculated using adjusted body weight. MDRD-4: the MDRD equation was calculated using four variables. MDRD-6: the MDRD equation was calculated using six variables. ${ }^{*} p<0.05$ using one-sided $t$ test indicating that the bias was significant.

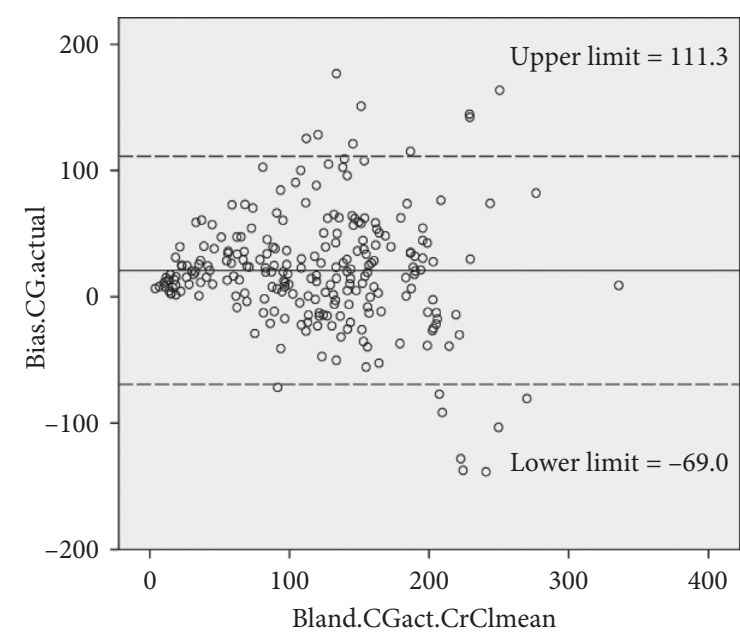

(a)

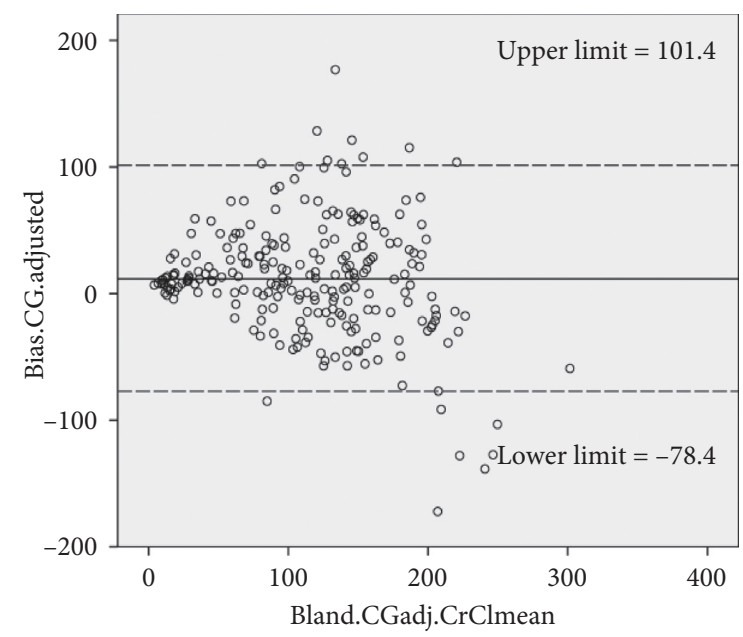

(c)

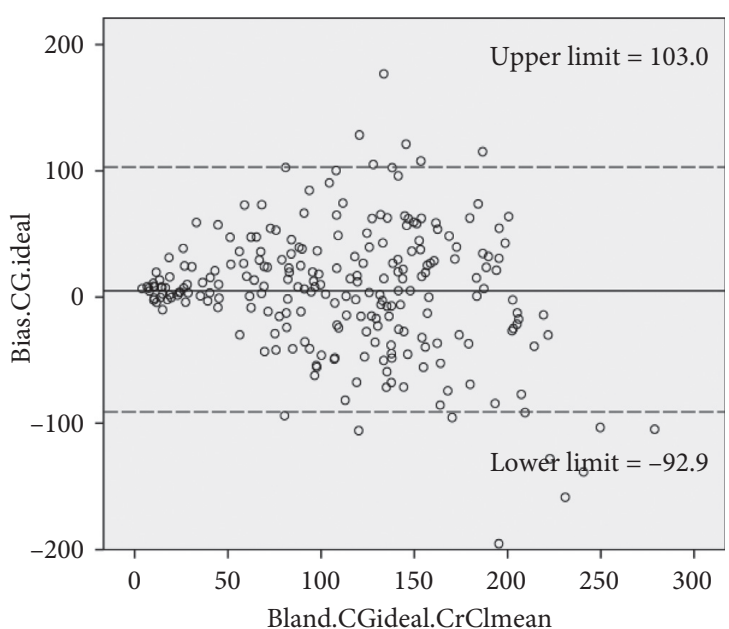

(b)

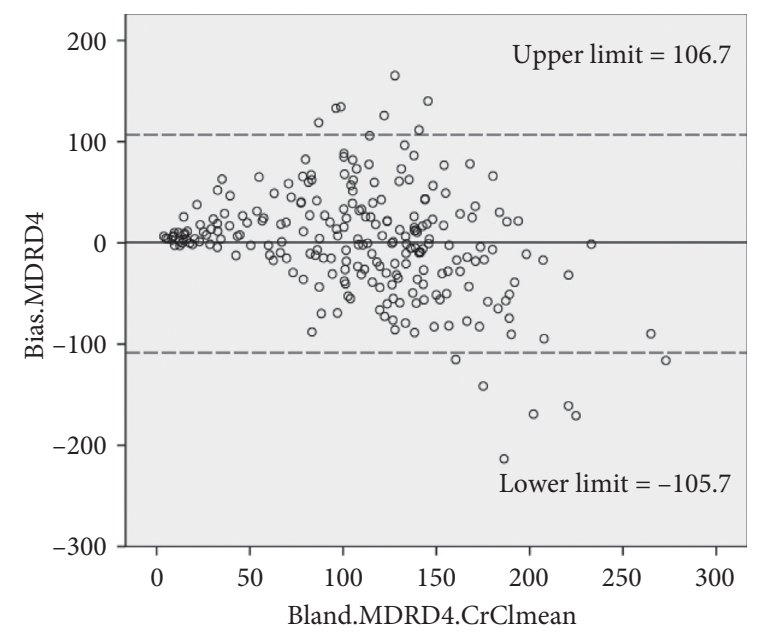

(d)

Figure 2: Continued. 


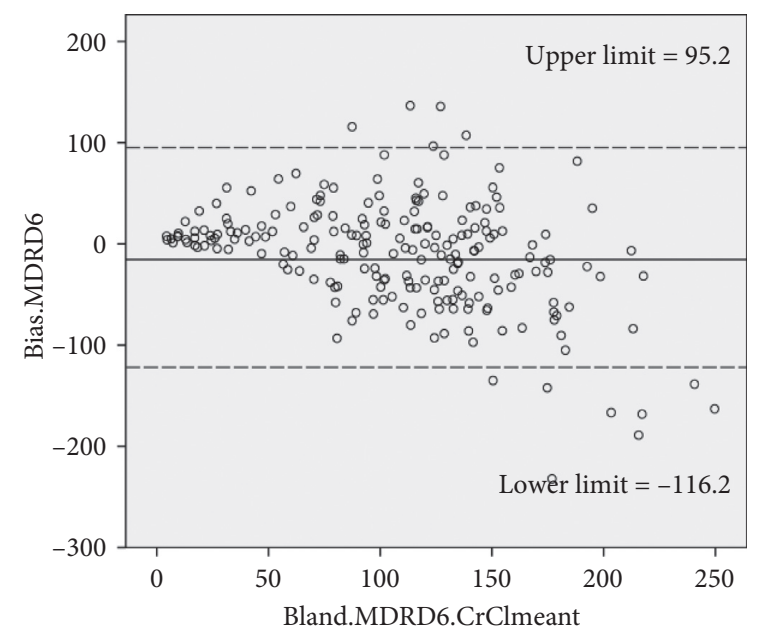

(e)

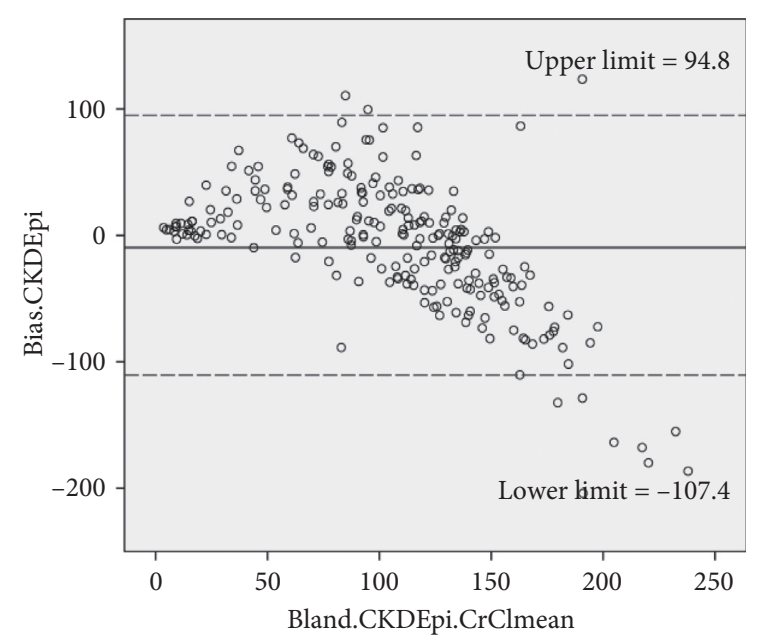

(f)

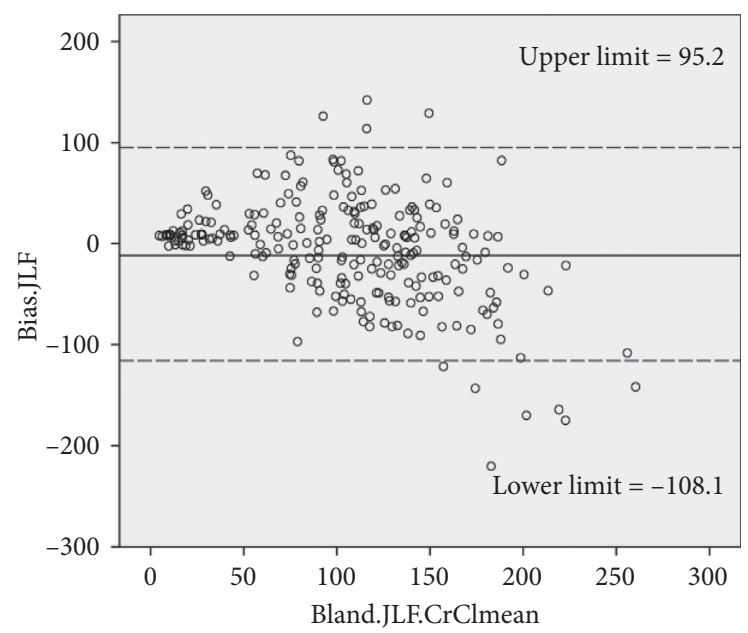

(g)

FiguRE 2: Bland-Altman plot of the creatinine clearance measured by 24-hour urine collection $\left(\mathrm{CrCl}_{24 \mathrm{~h} \text {-urine }}\right)$ versus the equations estimating glomerular filtration rate. (a) Cockroft-Gault equation using actual body weight; (b) Cockroft-Gault equation using ideal body weight; (c) Cockroft-Gault equation using adjusted body weight; (d) 4-variable modification of diet in renal disease equation; (e) 6-variable modification of diet in renal disease equation; ( $f$ ) chronic kidney disease epidemiology collaboration equation; and (g) Jelliffe equation. The $X$-axis represents the difference between $\mathrm{CrCl}_{24 \mathrm{~h} \text {-urine }}$ and the equation estimating glomerular filtration rate. The $Y$-axis represents the mean of $\mathrm{CrCl}_{24 \mathrm{~h} \text {-urine }}$ and the equation estimating glomerular filtration rate. The solid line represents the bias (mean difference obtained across the range of values), whereas the dashed lines are the limits of agreement $( \pm 1.96 \times$ standard deviation).

equations, CG, MDRD-4, and CKD-EPI equations, performed poorly when compared with measured GFR. The biases ranged from $7.4 \mathrm{ml} / \mathrm{min}$ for $\mathrm{CG}_{\text {actual-wt }}$ to $11.6 \mathrm{ml} / \mathrm{min}$ for MDRD-4 [15]. Additionally, the limits of agreement were wide for all the equations [15]. We found that the bias was generally high, but MDRD-6 had the lowest bias $(28.4 \mathrm{ml} /$ min). Jelliffe equation had the highest accuracy $\pm 30 \%$, but was only $35.3 \%$. The correlations of studies equations with $\mathrm{CrCl}_{24 \text {-urine }}$ were fair. Moreover, MDRD-6 had the highest sensitivity $(39.1 \%)$ to correctly classify $\mathrm{CrCl}_{24 \mathrm{~h} \text {-urine }}$ $30-59.9 \mathrm{ml} / \mathrm{min}$. This was mostly due to overestimation of GFR.

Other studies evaluated GFR-estimating equations in patents with ARC. A study of 390 patients with ARC in a surgical ICU in Belgium showed fair correlation between measured and estimated clearances (Spearman $r=0.34$; $p<0.001$ for CG equation and $0.29 ; p<0.001$ for MDRD-4 equation) [14]. The bias was $-11.2 \mathrm{ml} / \mathrm{min}$ with limits of agreement $(-131.7 ; 109.3 \mathrm{ml} / \mathrm{min})$ for CG equation and $-19.9 \mathrm{ml} / \mathrm{min}$ with limits of agreement $(-170.4 ; 130.7 \mathrm{ml} /$ min) for MDRD-4 [14]. Post hoc analysis of prospectively collected data in 86 patients with ARC at two tertiary ICUs in Australia and Portugal found that GFR estimated by CG, modified CG, MDRD-4, and MDRD-6 equations signifi-

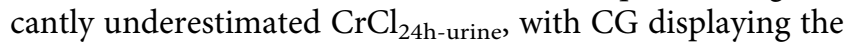
smallest bias [13]. The correlation was poor between $\mathrm{CrCl}_{24 \mathrm{~h}}$ urine and CG $(r=0.26, p=0.02)$ and MDRD-4 $(r=0.22$, $p=0.047$ ), and neither had acceptable precision for clinical application in this setting [13]. CG estimates had the highest sensitivity for correctly identifying ARC (62\%) [13]. In the 
TABLE 4: Correlation between equations estimating glomerular filtration rate and creatinine clearance measured by 24 -hour urine collection.

\begin{tabular}{|c|c|c|c|c|c|c|c|}
\hline & \multicolumn{7}{|c|}{ Spearman correlation $(r)$} \\
\hline & $\mathrm{CG}_{\text {actual-wt }}$ & $\mathrm{CG}_{\text {ideal-wt }}$ & $\mathrm{CG}_{\text {adjusted-wt }}$ & MDRD-4 & MDRD-6 & CKD-EPI & Jelliffe \\
\hline Age $\geq 65$ years $(N=53)$ & 0.70 & 0.62 & 0.67 & 0.60 & 0.61 & 0.67 & 0.61 \\
\hline Age $<65$ years $(N=184)$ & 0.71 & 0.62 & 0.69 & 0.57 & 0.56 & 0.57 & 0.58 \\
\hline $\mathrm{BMI} \geq 30 \mathrm{~kg} / \mathrm{m}^{2}(N=77)$ & 0.82 & 0.82 & 0.83 & 0.76 & 0.73 & 0.81 & 0.78 \\
\hline $\mathrm{BMI}<30 \mathrm{~kg} / \mathrm{m}^{2}(N=160)$ & 0.73 & 0.73 & 0.73 & 0.61 & 0.64 & 0.63 & 0.64 \\
\hline Admission category: medical $(N=112)$ & 0.79 & 0.72 & 0.78 & 0.63 & 0.66 & 0.70 & 0.67 \\
\hline Admission category: surgical $(N=11)$ & 0.74 & 0.58 & 0.68 & 0.70 & 0.48 & 0.66 & 0.67 \\
\hline Admission category: nonoperative trauma $(N=114)$ & 0.54 & 0.37 & 0.46 & 0.34 & 0.30 & 0.22 & 0.32 \\
\hline APACHE II $\geq 20(N=118)$ & 0.77 & 0.74 & 0.77 & 0.68 & 0.67 & 0.71 & 0.71 \\
\hline APACHE II < $20(N=119)$ & 0.71 & 0.59 & 0.67 & 0.48 & 0.46 & 0.53 & 0.55 \\
\hline Diabetes $(N=75)$ & 0.78 & 0.70 & 0.77 & 0.65 & 0.62 & 0.67 & 0.68 \\
\hline No diabetes $(N=162)$ & 0.70 & 0.62 & 0.68 & 0.52 & 0.52 & 0.57 & 0.55 \\
\hline Sepsis admission $(N=51)$ & 0.76 & 0.74 & 0.77 & 0.62 & 0.64 & 0.69 & 0.65 \\
\hline No sepsis on admission $(N=186)$ & 0.74 & 0.66 & 0.72 & 0.59 & 0.57 & 0.61 & 0.62 \\
\hline Traumatic brain injury $(N=62)$ & 0.56 & 0.39 & 0.49 & 0.41 & 0.43 & 0.21 & 0.32 \\
\hline No traumatic brain injury $(N=175)$ & 0.78 & 0.72 & 0.77 & 0.64 & 0.63 & 0.70 & 0.67 \\
\hline SOFA renal $>0(\mathrm{Cr} \geq 110 \mu \mathrm{mol} / \mathrm{L})(N=49)$ & 0.90 & 0.86 & 0.90 & 0.82 & 0.82 & 0.81 & 0.85 \\
\hline SOFA renal $=0(\mathrm{Cr}<110 \mu \mathrm{mol} / \mathrm{L})(\mathrm{N}=188)$ & 0.64 & 0.54 & 0.62 & 0.41 & 0.43 & 0.45 & 0.46 \\
\hline Acute kidney injury on admission $(N=43)$ & 0.79 & 0.68 & 0.75 & 0.68 & 0.63 & 0.68 & 0.70 \\
\hline No acute kidney injury on admission $(N=188)$ & 0.65 & 0.56 & 0.63 & 0.41 & 0.45 & 0.46 & 0.47 \\
\hline Baseline $\mathrm{CrCl}_{24 \mathrm{~h} \text {-urine }} \geq 130 \mathrm{ml} / \mathrm{min}(N=91)$ & 0.38 & 0.26 & 0.36 & 0.27 & 0.17 & 0.22 & 0.23 \\
\hline Baseline $\mathrm{CrCl}_{24 \mathrm{~h} \text {-urine }}<130 \mathrm{ml} / \mathrm{min}(N=146)$ & 0.70 & 0.68 & 0.70 & 0.62 & 0.62 & 0.71 & 0.64 \\
\hline
\end{tabular}

APACHE: acute physiology and chronic health evaluation; BMI: body mass index; CKD-EPI: chronic kidney disease epidemiology collaboration; CG:

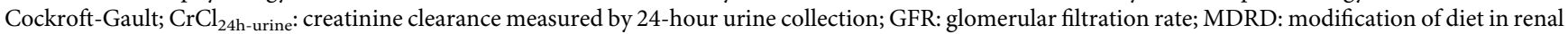
disease study. $\mathrm{CG}_{\text {actual-wt }}$ the $\mathrm{CG}$ equation was calculated using actual body weight. $\mathrm{CG}_{\text {ideal-wt: the }} \mathrm{CG}$ equation was calculated using ideal body weight. $\mathrm{CG}_{\text {adjusted-wt }}$ the $\mathrm{CG}$ equation was calculated using adjusted body weight. MDRD-4: the MDRD equation was calculated using four variables. MDRD-6: the MDRD equation was calculated using six variables.

current study, we found lower bias when $\mathrm{CrCl}_{24 \mathrm{~h}}$ urine $\geq 130 \mathrm{ml} / \mathrm{min}$ than lower ranges. $\mathrm{CG}_{\text {adjusted-wt had low }}$ bias $(-0.7 \mathrm{ml} / \mathrm{min})$, the highest accuracy $\pm 30 \%(75.2 \%)$, and sensitivity to correctly classify $\mathrm{CrCl}_{24 \mathrm{~h} \text {-urine }} \geq 130 \mathrm{ml} / \mathrm{min}$ (79.1\%). It should be noted that failure to correctly identify ARC may lead to subtherapeutic dosing of medications increasing the risk of treatment failure, emerging microbial resistance, prolonged ICU stay, and increased mortality [29].

GFR-estimating equations may not perform well in certain populations, such as the very elderly [30,31], patients with diabetes [32], or those who have liver cirrhosis [33]. We studied subgroups of ICU patients and found that the

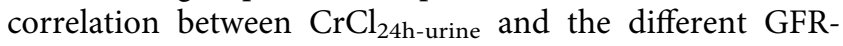
estimating equations was weak in patients with polytrauma, who commonly have ARC [34].

The findings of this study should be interpreted taking into consideration its strengths and limitations. The strength includes the prospective data collection, relatively large sample size, the study of seven GFR-estimating equations, and the evaluation of their performance using several methods. The limitations include being a single-center study and the use of $\mathrm{CrCl}_{24 \mathrm{~h} \text {-urine }}$ instead of more accurate GFR measures (e.g., inulin, ${ }^{125}$ I-sodium iothalamate clearance or cystatin C-based equations). Serum cystatin C-based equations have been found to outperform serum creatine-based equations in estimating GFR in critically ill patients [35-37]. Moreover, $\mathrm{CrCl}_{24 \text { h-urine }}$ is less accurate when kidney function is not steady and dysfunction is evolving [15], which is frequent in the ICU.

In conclusion, GFR-estimating equations that are commonly used in clinical practice had limited ability to

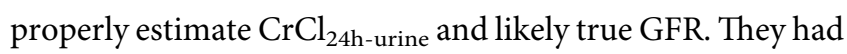
limited ability to correctly classify GFR into clinically relevant ranges that are usually needed to determine dosing of medications. The clinical significance of these findings needs to be studied further.

\section{Data Availability}

The datasets used and/or analyzed during the current study are available from the corresponding author on reasonable request.

\section{Ethical Approval}

The PermiT trial was approved by the Institution Review Board of the Ministry of National Guard Health Affairs, Riyadh, Saudi Arabia.

\section{Consent}

Informed consent was obtained from enrolled patients/next of kin.

\section{Conflicts of Interest}

All authors declare no conflicts of interest.

\section{Authors' Contributions}

Conception and design of the work was performed by HMD and YMA. Acquisition of data was done by AAA, ASA, 
AMA, and MS. Analysis and interpretation of data were carried out by HMD, HT, AAA, ASA, AMA, MS, EE, and YMA. Manuscript was drafted by HMD. Manuscript was revised by HMD, HT, AAA, ASA, AMA, MS, EE, and YMA. All authors read and approved the final manuscript.

\section{Acknowledgments}

The PermiT trial was funded by King Abdullah International Medical Research Center, Riyadh, Saudi Arabia.

\section{References}

[1] K. M. Andrassy, "Comments on "KDIGO 2012 clinical practice guideline for the evaluation and management of chronic kidney disease"” Kidney International, vol. 84, no. 3, pp. 622-623, 2013.

[2] C. A. Johnson, A. S. Levey, J. Coresh, A. Levin, J. Lau, and G. Eknoyan, "Clinical practice guidelines for chronic kidney disease in adults: part I. definition, disease stages, evaluation, treatment, and risk factors," American Family Physician, vol. 70, no. 5, pp. 869-876, 2004.

[3] D. Tejera, F. Varela, D. Acosta et al., "Epidemiology of acute kidney injury and chronic kidney disease in the intensive care unit," Revista Brasileira de Terapia Intensiva, vol. 29, no. 4, pp. 444-452, 2017.

[4] A. A. Udy, J. P. Baptista, N. L. Lim et al., "Augmented renal clearance in the ICU," Critical Care Medicine, vol. 42, no. 3, pp. 52-527, 2014.

[5] F. B. Sime, A. A. Udy, and J. A. Roberts, "Augmented renal clearance in critically ill patients: etiology, definition and implications for beta-lactam dose optimization," Current Opinion in Pharmacology, vol. 24, pp. 1-6, 2015.

[6] A. Kumar, D. Roberts, K. E. Wood et al., "Duration of hypotension before initiation of effective antimicrobial therapy is the critical determinant of survival in human septic shock," Critical Care Medicine, vol. 34, no. 6, pp. 1589-1596, 2006.

[7] C. W. Seymour, F. Gesten, H. C. Prescott et al., "Time to treatment and mortality during mandated emergency care for sepsis," New England Journal of Medicine, vol. 376, no. 23, pp. 2235-2244, 2017.

[8] D. W. Cockcroft and H. Gault, "Prediction of creatinine clearance from serum creatinine," Nephron, vol. 16, no. 1, pp. 31-41, 1976.

[9] A. S. Levey, J. Bosch, J. Lewis, T. Greene, N. Rogers, and D. Roth, "A more accurate method to estimate glomerular filtration rate from serum creatinine: a nesw prediction equation," Annals of Internal Medicine, vol. 130, no. 6, pp. 461-470, 1999.

[10] A. S. Levey, L. A. Stevens, C. H. Schmid et al., "A new equation to estimate glomerular filtration rate," Annals of Internal Medicine, vol. 150, no. 9, pp. 604-612, 2009.

[11] R. W. Jelliffe, "Creatinine clearance: bedside estimate," Annals of Internal Medicine, vol. 79, no. 4, p. 604, 1973.

[12] J. H. Martin, M. F. Fay, and J. P. Ungerer, "eGFR-use beyond the evidence," Medical Journal of Australia, vol. 190, no. 4, pp. 197-199, 2009.

[13] J. Baptista, A. A. Udy, E. Sousa et al., "A comparison of estimates of glomerular filtration in critically ill patients with augmented renal clearance," Critical Care, vol. 15, no. 3, p. R139, 2011.

[14] V. Grootaert, L. Willems, Y. Debaveye, G. Meyfroidt, and I. Spriet, "Augmented renal clearance in the critically ill: how to assess kidney function," Ann Pharmacother, vol. 46, no. 7-8, pp. 952-959, 2012.

[15] G. Bragadottir, B. Redfors, and S.-E. Ricksten, "Assessing glomerular filtration rate (GFR) in critically ill patients with acute kidney injury-true GFR versus urinary creatinine clearance and estimating equations," Critical Care, vol. 17, no. 3, p. R108, 2013.

[16] J. P. Baptista, M. Neves, L. Rodrigues, L. Teixeira, J. Pinho, and J. Pimentel, "Accuracy of the estimation of glomerular filtration rate within a population of critically ill patients," Journal of Nephrology, vol. 27, no. 4, pp. 403-410, 2014.

[17] M. Carlier, A. Dumoulin, A. Janssen et al., "Comparison of different equations to assess glomerular filtration in critically ill patients," Intensive Care Medicine, vol. 41, no. 3, pp. 427-435, 2015.

[18] Y. M. Arabi, A. S. Aldawood, S. H. Haddad et al., "Permissive underfeeding or standard enteral feeding in critically ill adults," New England Journal of Medicine, vol. 372, no. 25, pp. 2398-2408, 2015.

[19] A. Khwaja, "KDIGO clinical practice guidelines for acute kidney injury," Nephron, vol. 120, no. 4, pp. c179-c184, 2012.

[20] L. B. Sheiner and S. L. Beal, "Some suggestions for measuring predictive performance," Journal of Pharmacokinetics and Biopharmaceutics, vol. 9, no. 4, pp. 503-512, 1981.

[21] L. Critchley and J. Critchley, "A meta-analysis of studies using bias and precision statistics to compare cardiac output measurement techniques," Journal of Clinical Monitoring and Computing, vol. 15, no. 2, pp. 85-91, 1999.

[22] National Kidney Foundation, "K/DOQI clinical practice guidelines for chronic kidney disease: evaluation, classification, and stratification," AAmerican Journal of Kidney Diseases, vol. 39, no. 2 S1, pp. S1-S266, 2002.

[23] J. M. Bland and D. G. Altman, "Statistical methods for assessing agreement between two methods of clinical measurement," Lancet (London, England), vol. 1, no. 8476, pp. 307-310, 1986.

[24] M. E. Thomas, C. Blaine, A. Dawnay et al., "The definition of acute kidney injury and its use in practice," Kidney International, vol. 87, no. 1, pp. 62-73, 2015.

[25] R. Jelliffe, "Estimation of creatinine clearance in patients with unstable renal function, without a urine specimen," American Journal of Nephrology, vol. 22, no. 4, pp. 320-324, 2002.

[26] S. Ruiz, V. Minville, K. Asehnoune et al., "Screening of patients with augmented renal clearance in ICU: taking into account the CKD-EPI equation, the age, and the cause of admission," Ann Intensive Care, vol. 5, no. 1, p. 49, 2015.

[27] D. Tsai, A. A. Udy, P. C. Stewart et al., "Prevalence of augmented renal clearance and performance of glomerular filtration estimates in Indigenous Australian patients requiring intensive care admission," Anaesthesia and Intensive Care, vol. 46, no. 1, pp. 42-50, 2018.

[28] Y. Kawano, S. Morimoto, Y. Izutani et al., "Augmented renal clearance in Japanese intensive care unit patients: a prospective study," Journal of Intensive Care, vol. 4, p. 62, 2016.

[29] A. A. Udy, J. M. Dulhunty, J. A. Roberts et al., "Association between augmented renal clearance and clinical outcomes in patients receiving $\beta$-lactam antibiotic therapy by continuous or intermittent infusion: a nested cohort study of the BLINGII randomised, placebo-controlled, clinical trial," International Journal of Antimicrobial Agents, vol. 49, no. 5, pp. 624-630, 2017.

[30] A. Chen, Y. Sun, W. Li et al., "Application of GFR estimation equations in elderly patients with measured GFR below $60 \mathrm{~mL} / \mathrm{min} / 1.73 \mathrm{~m}^{2}, "$ Aging Clinical and Experimental Research, vol. 32, no. 3, pp. 415-422, 2020. 
[31] J. C. Verhave, P. Fesler, J. Ribstein, G. du Cailar, and A. Mimran, "Estimation of renal function in subjects with normal serum creatinine levels: influence of age and body mass index," American Journal of Kidney Diseases, vol. 46, no. 2, pp. 233-241, 2005.

[32] S. Luis-Lima and E. Porrini, "An overview of errors and flaws of estimated GFR versus true GFR in patients with diabetes mellitus," Nephron, vol. 136, no. 4, pp. 287-291, 2017.

[33] C. Francoz, D. Prié, W. Abdelrazek et al., "Inaccuracies of creatinine and creatinine-based equations in candidates for liver transplantation with low creatinine: impact on the model for end-stage liver disease score," Liver Transplantation, vol. 16, no. 10, pp. 1169-1177, 2010.

[34] A. Udy, R. Boots, S. Senthuran et al., "Augmented creatinine clearance in traumatic brain injury," Anesthesia \& Analgesia, vol. 111, no. 6, pp. 1505-1510, 2010.

[35] S. Herget-Rosenthal, G. Marggraf, J. Hüsing et al., "Early detection of acute renal failure by serum cystatin C," Kidney International, vol. 66, no. 3, pp. 1115-1122, 2004.

[36] J. Eiamcharoenying, W. Kulvichit, N. Lumlertgul, T. Chaiwatanarat, S. Peerapornratana, and N. Srisawat, "The role of serum cystatin $\mathrm{C}$ in estimation of renal function in survivors of critical illness," Journal of Critical Care, vol. 59, pp. 201-206, 2020.

[37] B. Ravn, J. R. Prowle, J. Mårtensson, C.-R. Martling, and M. Bell, "Superiority of serum cystatin C over creatinine in prediction of long-term prognosis at discharge from ICU," Critical Care Medicine, vol. 45, no. 9, pp. e932-e940, 2017. 